\title{
Paraferrimonas sedimenticola gen. nov., sp. nov., a marine bacterium of the family Ferrimonadaceae
}

\author{
Shams Tabrez Khan and Shigeaki Harayama \\ Biological Resource Center (NBRC), National Institute of Technology and Evaluation (NITE), \\ 2-5-8 Kazusa-kamatari, Kisarazu, Chiba 292-0818, Japan
}

Correspondence

Shams Tabrez Khan

shams-tabrez-khan@nite.go.jp

\begin{abstract}
Three strains (Mok-106 ${ }^{\top}$, Mok-142 and Mok-143) were isolated from marine sediment samples collected from the coast of Okinawa Island, Japan. On the basis of 16S rRNA gene sequence comparisons, the isolates were affiliated with the family Ferrimonadaceae; Shewanella denitrificans and Ferrimonas balearica were the closest relatives, having sequence similarities of 93.7 and 93.0\%, respectively. The novel isolates shared high levels of 16S rRNA gene sequence similarity with each other (98.7-99.3\%) and the results of DNA-DNA hybridization indicated that the three strains belong to the same species. The cells were rod-shaped, motile by means of single polar flagellum and formed colonies that produced a rose-coloured pigment within 6 days incubation at $25^{\circ} \mathrm{C}$. The isolates grew in the presence of $0.5-4.0 \%(\mathrm{w} / \mathrm{v}) \mathrm{NaCl}$ and at $15-40{ }^{\circ} \mathrm{C}$. The major

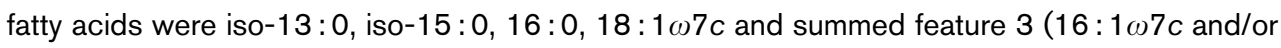
iso-15:0 2-OH). Menaquinone- 6 , menaquinone- 7 and ubiquinone-8 were the major quinones and the major polar lipids were phosphatidylethanolamine and phosphatidylglycerol. The DNA $\mathrm{G}+\mathrm{C}$ content was 50-51 mol\%. Phylogenetic and phenotypic analyses of these isolates suggested that they belong to a novel genus and species of the family Ferrimonadaceae, for which the name Paraferrimonas sedimenticola gen. nov., sp. nov. is proposed. The type strain is Mok-106 ${ }^{\top}\left(=\right.$ NBRC $101628^{\top}=$ CIP $\left.109284^{\top}\right)$.
\end{abstract}

The family Ferrimonadaceae was proposed by Ivanova et al. (2004) and is currently represented by a single genus, Ferrimonas, comprising four species: Ferrimonas balearica (Rosselló-Mora et al., 1995), Ferrimonas marina (Katsuta et al., 2005), Ferrimonas futtsuensis and Ferrimonas kyonanensis (Nakagawa et al., 2006). The initial description of the family was based on the characteristics of F. balearica, which was originally the sole member of the family (Rosselló-Mora et al., 1995). Thus, the family was defined by the following features: facultatively anaerobic, Gram-negative, motile rods, nitrate-reducing and $\mathrm{NaCl}$-requiring and having iso$15: 0,16: 1 \omega 9 c$ and $17: 1 \omega 9 c$ as the major fatty acids. Later, phenotypic characterization of the three newly described species, F. marina (Katsuta et al., 2005), F. futtsuensis and F. kyonanensis (Nakagawa et al., 2006), demonstrated that

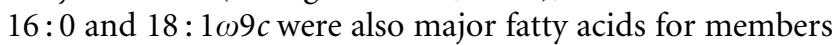
of the Ferrimonadaceae and that the DNA G $+\mathrm{C}$ content of the family was $57-61 \mathrm{~mol} \%$.

Abbreviations: HSMA, half-strength marine agar 2216; PE, phosphatidylethanolamine; PG, phosphatidylglycerol.

The GenBank/EMBL/DDBJ accession numbers for the 16S rRNA gene sequences of strains Mok-106 ${ }^{\top}$, Mok-142 and Mok-143 are $A B 252732, A B 252733$ and AB252734, respectively.

A table detailing DNA-DNA hybridization values (\%) between strains Mok-106 ${ }^{\top}$, Mok-142 and Mok-143 and a figure showing the polar lipid TLC plate are available with the online version of this paper.
In this study, three novel strains belonging to the class Gammaproteobacteria were isolated. These strains were subjected to a polyphasic taxonomic analysis. On the basis of the results obtained, it is concluded that these strains should be classified as representing members of a novel genus of the family Ferrimonadaceae.

Strains Mok-106 ${ }^{\mathrm{T}}$, Mok-142 and Mok-143 were isolated from a marine sediment sample collected from the coast of Okinawa Island, Japan, by using the standard dilution plating technique at $25^{\circ} \mathrm{C}$ on half-strength marine broth 2216 (MB; Difco) plates solidified with $1.5 \%(\mathrm{w} / \mathrm{v})$ agar (HSMA plates). For morphological and biochemical characterizations, the strains were grown under the same conditions unless specified otherwise. Colonies on HSMA plates appeared colourless in the first 3-5 days but produced a rose-coloured pigment after longer periods of incubation. Gram staining was determined as described by Cowan \& Steel (1993). Cells from 2-day-old cultures on HSMA plates were negatively stained with $1 \%(\mathrm{w} / \mathrm{v})$ phosphotungstic acid and observed under a transmission electron microscope (H7600; Hitachi). Strains Mok-106 ${ }^{\mathrm{T}}$, Mok-142 and Mok143 were found to comprise Gram-negative, rod-shaped bacteria measuring $0.7-1.0 \mu \mathrm{m}$ in width and $1.5-2.0 \mu \mathrm{m}$ in length. Cells were motile by means of single polar flagellum.

Growth at different temperatures was checked on HSMA plates incubated at $4,10,15,20,30,37,40,42$ and $45^{\circ} \mathrm{C}$. 
Growth was observed at $15-40{ }^{\circ} \mathrm{C}$, the optimal temperature being $25-30^{\circ} \mathrm{C}$. Growth was not observed at $4,10,42$ or $45^{\circ} \mathrm{C}$. Tolerance of and requirement for $\mathrm{NaCl}$ were tested on triple-sugar-iron agar (Difco) supplemented with 0, 0.5, 1, $2,3,4,5,6,7,8,9$ and $10 \%(\mathrm{w} / \mathrm{v}) \mathrm{NaCl}$. $\mathrm{NaCl}$ was found to be required for growth on triple-sugar-iron agar, as the strains did not grow at $0 \% \mathrm{NaCl}$. Growth was inhibited by $\mathrm{NaCl}$ at concentrations higher than $4.0 \%(\mathrm{w} / \mathrm{v})$. Growth at different $\mathrm{pH}$ values was tested on HSMA plates with $\mathrm{pH}$ values adjusted to $5,6,7,8,9,10$ and 11 . The three novel strains grew at $\mathrm{pH} 6-11$ and grew very weakly at $\mathrm{pH}$ 5.0.

Anaerobic growth with different combinations of electron acceptors [ferric citrate $(10 \mathrm{mM})$, ferric-EDTA $(10 \mathrm{mM})$, manganese(IV)-oxide $\left(0.3 \mathrm{~g}_{10 \mathrm{ml}^{-1}}\right)$, elemental sulfur $(1 \%, \mathrm{w} / \mathrm{v})$, thiosulfate $(5 \mathrm{mM})$, sulfate $(5 \mathrm{mM})$ and nitrate $(10 \mathrm{mM})$ ] and donors [yeast extract $(0.2 \%, \mathrm{w} / \mathrm{v})$, lactate $(10 \mathrm{mM})$, acetate $(10 \mathrm{mM})$, pyruvate $(10 \mathrm{mM})$, glucose $(10 \mathrm{mM})$ and $\mathrm{H}_{2} / \mathrm{CO}_{2}(80: 20$, v/v)] was tested in modified bicarbonate-buffered medium (MBB medium) according to the protocol of Nakagawa et al. (2006). MBB medium consisted of a basal medium $\left(20 \mathrm{~g} \mathrm{NaCl} 1^{-1} ; 3 \mathrm{~g}\right.$ $\mathrm{MgCl}_{2} .6 \mathrm{H}_{2} \mathrm{O} \mathrm{l}^{-1} ; 0.15 \mathrm{~g} \mathrm{CaCl}_{2} \cdot 2 \mathrm{H}_{2} \mathrm{O} \mathrm{l}^{-1} ; 0.25 \mathrm{~g} \mathrm{NH}_{4} \mathrm{Cl}$ $\mathrm{l}^{-1} ; 0.2 \mathrm{~g} \mathrm{KH}_{2} \mathrm{PO}_{4} \mathrm{l}^{-1} ; 0.5 \mathrm{~g} \mathrm{KCl}^{-1}$ ) to each litre of which were added the following components: $30 \mathrm{ml}$ bicarbonate solution (84 $\left.\mathrm{g} \mathrm{NaHCO}_{3} \mathrm{l}^{-1}\right), 1 \mathrm{ml}$ vitamin mixture (4 mg 4-aminobenzoic acid, $1 \mathrm{mg}$ biotin, $10 \mathrm{mg}$ nicotinic acid, $5 \mathrm{mg}$ calcium D-pantothenate and $15 \mathrm{mg}$ pyridoxine dihydrochloride dissolved in $100 \mathrm{ml} 10 \mathrm{mM}$ sodium phosphate buffer, $\mathrm{pH} 7.1), 1 \mathrm{ml}$ non-chelated trace element mixture (Widdel et al., 1983), $1 \mathrm{ml}$ selenite-tungstate solution $\left(0.4 \mathrm{~g} \mathrm{NaOH} \mathrm{l}^{-1} ; 6 \mathrm{mg} \mathrm{Na} 2 \mathrm{SeO}_{3} .5 \mathrm{H}_{2} \mathrm{O} \mathrm{l}^{-1} ; 9 \mathrm{mg}\right.$ $\mathrm{Na}_{2} \mathrm{WO}_{4} \cdot 2 \mathrm{H}_{2} \mathrm{O} \mathrm{l}^{-1}$ ), $1 \mathrm{ml}$ thiamine solution $(100 \mathrm{mg}$ thiamine dihydrochloride $\mathrm{l}^{-1}$ dissolved in $25 \mathrm{mM}$ sodium phosphate buffer, $\mathrm{pH}$ 3.4) and $1 \mathrm{ml}$ vitamin $\mathrm{B}_{12}$ solution (50 $\mathrm{mg} \mathrm{l}^{-1}$ cyanocobalamin). The $\mathrm{pH}$ of the medium was adjusted to 7.0 with $1 \mathrm{M} \mathrm{HCl}$ or $1 \mathrm{M} \mathrm{CaCO}_{3}$. Electron donors and acceptors were autoclaved separately and were added to the medium after autoclaving.

Strains Mok-106 ${ }^{\mathrm{T}}$, Mok-142 and Mok-143 grew aerobically in MBB medium with yeast extract as an electron donor but not with other electron donors. They failed to grow anaerobically in MBB medium with any of the combinations of the electron acceptors and donors tested. Anaerobic growth was also tested on MBB agar $(1.5 \%$, w/v) plates with yeast extract $(0.2 \%, \mathrm{w} / \mathrm{v})$ as the electron donor and $10 \mathrm{mM}$ nitrate, $10 \mathrm{mM}$ ferric citrate or $10 \mathrm{mM}$ ferric-EDTA as the electron acceptor. The growth of the three novel strains was compared with the growth of F. balearica DSM $9799^{\mathrm{T}}$ on the same plates. After anaerobic incubation at $25^{\circ} \mathrm{C}$ for 8-10 days in Anaeropack jars (Mitsubishi Gas Chemical), weak growth of the three novel strains was observed with ferric citrate and ferric-ETDA as electron acceptors; the yellowish $\mathrm{Fe}(\mathrm{III})$ precipitate around colonies of the novel strains was cleared, indicating the reduction of $\mathrm{Fe}(\mathrm{III})$ to $\mathrm{Fe}(\mathrm{II})$. With nitrate, growth of the strains was not observed. In contrast, F. balearica grew well anaerobically with all of the three electron acceptors tested and yeast extract as the electron donor. All of the novel strains and F. balearica grew well with yeast extract under aerobic conditions.

The presence of catalase was tested by flooding 2-day-old colonies developed on marine agar 2216 (Difco) with $3 \%$ (v/v) $\mathrm{H}_{2} \mathrm{O}_{2}$; the formation of oxygen bubbles was considered as a catalase-positive result. Cell suspensions in sterile water, made using 2-day-old cultures, were spotted on cytochrome oxidase strips (Nissui Pharmaceutical). A change in colour from white to blue was taken as a positive result indicating the presence of oxidase. Degradation of casein, starch and DNA was tested as described by Cowan \& Steel (1993). The novel strains tested positive for catalase, oxidase and DNase, but negative for the degradation of starch and casein. Degradation of agar was tested on HSMA plates and the novel strains gave a negative result.

Nitrate reduction, indole production from tryptophan, acid production from glucose, the presence of urease, the hydrolysis of aesculin and the liquefaction of gelatin were tested by using API 20NE strips (bioMérieux). The manufacturer's instructions were followed except that artificial seawater (Naigai Chemicals) was used to prepare the inocula. With the API 20NE strips, the strains tested positive for degradation of aesculin and gelatin and for nitrate reduction, but were negative for nitrite reduction, urease, acid production from glucose and indole production from tryptophan.

Biolog GN2 MicroPlates (Biolog) were used to test for the oxidation of different carbon sources. Inocula were prepared as suggested by Rüger \& Krambeck (1994). Of the 95 different carbon sources included in the GN2 MicroPlate, only Tween 40, L-alanine and glycyl L-glutamic acid were oxidized by all three novel strains, while $\alpha$-D-glucose, acetic acid, L-alanyl glycine, glycyl L-aspartic acid and L-threonine were oxidized only by strains Mok-142 and Mok-143. The utilization of various carbon sources (acetate, sodium lactate, glycine, trisodium citrate, D-maltose, L-glutamate, D-glucose, sodium malate, D-galactose, succinate, yeast extract and tryptone) was also checked in minimal medium as described by Suzuki et al. (2001). Of the carbon sources tested, the novel strains utilized only yeast extract and tryptone.

Cells for cellular fatty acid analysis were grown in $\mathrm{MB}$ at $25^{\circ} \mathrm{C}$ for $24 \mathrm{~h}$. The fatty acid analysis was performed according to the protocol of the Sherlock Microbial Identification System (MIDI). The whole-cell fatty acid profiles for the three Mok strains are shown in Table 1. Although the profiles were similar to those of Ferrimonas strains, some significant differences, such as the absence of iso- $16: 1 \omega 9 c$ (one of the major fatty acids in members of the genus Ferrimonas) were observed. Polar lipids were extracted from $100 \mathrm{mg}$ freeze-dried cells (Minnikin et al., 1979) of the novel Mok strains grown in MB. Polar lipids were separated by two-dimensional TLC using Kieselgel 60 $\mathrm{F}_{254}$ plates (Merck). The TLC plates were sprayed with $10 \%$ $(\mathrm{w} / \mathrm{v})$ molybdophosphoric acid in ethanol and incubated at 
Table 1. Fatty acid contents (\% of total) for strains Mok$106^{\top}$, Mok-142, Mok-143 and related species of the genus Ferrimonas

Strains: 1, strain Mok- $106^{\mathrm{T}}$; 2, strain Mok-142; 3, strain Mok-143; 4, F. balearica DSM $9799^{\mathrm{T}} ; 5$, F. marina A4D-4 ${ }^{\mathrm{T}} ; 6$, F. futtsuensis FUT3661 ${ }^{\mathrm{T}}$; 7, F. kyonanensis Asr $22-7^{\mathrm{T}}$. Values less than $1 \%$ of the total are not shown. Data for F. futtsuensis and F. kyonanensis are taken from Nakagawa et al. (2006) and data for F. balearica and F. marina are taken from Katsuta et al. (2005). In addition to the fatty acids given in the table, the following trace fatty acids were found in the three novel Mok strains: 12:0, 11:0 3-OH, 13:0, $12: 03-\mathrm{OH}, 14: 0$, iso-15:1 F, summed feature 1 , anteiso-15:0, $15: 1 \omega 6 c, 15: 1 \omega 8 c$, iso- $14: 03-\mathrm{OH}, 16: 1 \omega 9 c$, iso-15:0 3-OH, $17: 1 \omega 6 c, 17: 0,18: 0$ and iso-19:0. NA, Data not available; tr, trace; - , negative.

\begin{tabular}{|c|c|c|c|c|c|c|c|}
\hline Fatty acid & 1 & 2 & 3 & 4 & 5 & 6 & 7 \\
\hline $12: 0$ & $\operatorname{tr}$ & $\operatorname{tr}$ & $\operatorname{tr}$ & NA & NA & 4 & 5 \\
\hline $12: 03-\mathrm{OH}$ & $\operatorname{tr}$ & $\operatorname{tr}$ & $\operatorname{tr}$ & NA & NA & 7 & 8 \\
\hline iso-13: 0 & 8 & 9 & 12 & NA & NA & $\operatorname{tr}$ & 1 \\
\hline iso-13:0 $3-\mathrm{OH}$ & 2 & 2 & 3 & NA & NA & 1 & $\operatorname{tr}$ \\
\hline $14: 0$ & $\operatorname{tr}$ & $\operatorname{tr}$ & $\operatorname{tr}$ & NA & NA & 4 & 5 \\
\hline iso- $14: 0$ & 1 & 3 & 3 & NA & NA & NA & NA \\
\hline anteiso-14:0 & - & - & - & - & 1 & NA & NA \\
\hline $15: 0$ & $\operatorname{tr}$ & $\operatorname{tr}$ & $\operatorname{tr}$ & 2 & 2 & $\operatorname{tr}$ & $\operatorname{tr}$ \\
\hline iso- $15: 0$ & 23 & 20 & 21 & 10 & 12 & 2 & 1 \\
\hline $16: 0$ & 7 & 10 & 8 & 13 & 14 & 19 & 16 \\
\hline iso- $16: 0$ & $\operatorname{tr}$ & $\operatorname{tr}$ & $\operatorname{tr}$ & - & 3 & NA & NA \\
\hline iso- $16: 1 \omega 7 c$ & - & - & - & 5 & 6 & NA & NA \\
\hline iso- $16: 1 \omega 9 c$ & $\operatorname{tr}$ & $\operatorname{tr}$ & $\operatorname{tr}$ & 10 & 7 & 20 & 28 \\
\hline $17: 0$ & $\operatorname{tr}$ & $\operatorname{tr}$ & $\operatorname{tr}$ & 8 & 5 & $\operatorname{tr}$ & $\operatorname{tr}$ \\
\hline iso- $17: 1 \omega 9 c$ & 3 & 4 & 4 & NA & NA & - & - \\
\hline iso- $17: 0$ & 5 & 3 & 2 & 2 & 4 & $\operatorname{tr}$ & - \\
\hline $17: 1 \omega 8 c$ & 6 & 4 & 4 & 13 & 7 & 2 & 2 \\
\hline $18: 0$ & $\operatorname{tr}$ & $\operatorname{tr}$ & $\operatorname{tr}$ & 4 & 4 & 2 & $\operatorname{tr}$ \\
\hline $18: 1 \omega 7 c$ & 9 & 10 & 6 & 5 & 9 & 4 & 2 \\
\hline $18: 1 \omega 9 c$ & 6 & 5 & 3 & 18 & 16 & 16 & 11 \\
\hline \multicolumn{8}{|c|}{ Summed features:* } \\
\hline 2 & 1 & 1 & 1 & NA & NA & $\operatorname{tr}$ & 3 \\
\hline 3 & 17 & 20 & 22 & NA & NA & 10 & 10 \\
\hline 4 & $\operatorname{tr}$ & $\operatorname{tr}$ & $\operatorname{tr}$ & NA & NA & 1 & 1 \\
\hline 7 & 2 & 1 & 2 & NA & NA & - & - \\
\hline
\end{tabular}

* Summed features are groups of two or three fatty acids that cannot be separated by GLC with the MIDI system. Summed feature 2, 12:0 ALDE and/or unknown fatty acid; summed feature 3, 16:1 $1 \omega 7 c$ and/ or iso-15: 0 2-OH; summed feature $4,18: 2 \omega 6 c$ and/or $18: 2 \omega 9 c$ and/ or anteiso-18:0; summed feature 7, 19:1 $\omega 6 c$ and/or 19:0 cyclo $\omega 10 c$.

$140{ }^{\circ} \mathrm{C}$ for $1 \mathrm{~h}$ to reveal the total lipid content. For the detection of specific functional groups, the following spray reagents were used: Zinzadze reagent for phosphate, ninhydrin for free amino groups, anisaldehyde/sulfuric acid for glycolipids and periodic acid-Schiff stain for vicinal hydroxyl groups. All of the novel strains were found to contain phosphatidylethanolamine (PE) and phosphatidylglycerol (PG) as their major polar lipids. In contrast, all of the Ferrimonas strains tested (F. balearica DSM $9799^{\mathrm{T}}, F$. marina $\mathrm{A} 4 \mathrm{D}-4^{\mathrm{T}}$, F. futtsuensis FUT3661 ${ }^{\mathrm{T}}$ and F. kyonanensis Asr22- $7^{\mathrm{T}}$ ) were found to have an unidentified ninhydrinpositive phospholipid in addition to PG and PE (see Supplementary Fig. S1 available in IJSEM Online).

Cells for the quinone analysis were harvested from a $24 \mathrm{~h}$ culture grown at $25^{\circ} \mathrm{C}$ in $\mathrm{MB}$. Isoprenoid quinones were extracted from the freeze-dried cells and analysed according to the protocol of Nakagawa \& Yamasato (1993). The quinone profiles of the three novel strains were as follows: Mok-106 ${ }^{\mathrm{T}}$ (Q-8, $77 \%$; MK-7, $17 \%$; MK-6, $5 \%$ ), Mok-142 (Q-8, 79\%; MK-7, 16\%; MK-6, 4\%) and Mok-143 (Q-8, $83 \%$; MK-7, $12 \%$; MK-6, $4 \%$ ). These profiles were different from those of the Ferrimonas strains, in which the main quinones were MK-7 (41-52\%), Q-8 (17-20\%) and Q-7 (16-31\%) (Table 2).

Genomic DNA was extracted using the protocol of Minamisawa (1990) and the chromosomal DNA G+C content was determined by using the HPLC method of Mesbah et al. (1989). The chromosomal DNA G + C content of the novel strains was found to be $50-51 \mathrm{~mol} \%$.

The isolates were characterized phylogenetically using $16 \mathrm{~S}$ rRNA gene sequencing. The gene was amplified by using a set of universal primers (27f and 1492r) as described by Hiraishi et al. (1994). BigDye terminator v3.1 and a 3730 DNA analyzer (Applied Biosystems) were used for sequencing the amplicons. Sequences were edited and assembled using the ATGC program (Genetyx). Comparisons of $16 \mathrm{~S}$ rRNA gene sequences against those in the GenBank/ DDBJ database were performed using BLAST (Altschul et al., 1990), while the alignment of related sequences was performed using CLUSTAL_X (Thompson et al., 1997). Phylogenetic trees were constructed by using the neighbour-joining (Saitou \& Nei, 1987), maximum-parsimony (Swofford, 2000) and maximum-likelihood (Adachi \& Hasegawa, 1996) algorithms. The topologies of the resulting trees were evaluated by bootstrap analyses based on 100, 100 and 1000 resamplings for the maximum-parsimony, maximum-likelihood and neighbour-joining analyses, respectively (Felsenstein, 1985). The three novel strains shared high levels of 16S rRNA gene sequence similarity (98.7-99.3\%) with each other. A BLAST search against the sequences in GenBank/DDBJ showed $F$. balearica (GenBank accession no. X93021) to be the closest relative of the novel strains, having a 16S rRNA gene similarity of $94 \%$. High levels of similarity (93.2-93.7\%) were also found with respect to the $16 \mathrm{~S}$ rRNA gene sequence of Shewanella denitrificans (accession no. AJ311964). In the maximum-likelihood (Fig. 1) tree, all three novel Mok strains formed a monophyletic cluster with the genus Ferrimonas that was supported by a moderate bootstrap value. As similar results were also obtained with the maximum-parsimony and neighbour-joining analyses, we concluded that the three novel Mok strains belong to the family Ferrimonadaceae. 
Table 2. Characteristics that differentiate strains Mok-106 ${ }^{\top}$, Mok-142 and Mok-143 from members of the genus Ferrimonas

Taxa: 1, strains Mok-106 ${ }^{\mathrm{T}}$, Mok-142 and Mok-14; 2, F. balearica; 3, F. marina; 4, F. futtsuensis; 5, F. kyonanensis. Data for F. futtsuensis and F. kyonanensis are taken from Nakagawa et al. (2006), while those for F. balearica and F. marina are from Katsuta et al. (2005). +, Positive; -, negative; tr, trace; $\mathrm{v}$, variable.

\begin{tabular}{|c|c|c|c|c|c|}
\hline Characteristic & 1 & 2 & 3 & 4 & 5 \\
\hline \multicolumn{6}{|l|}{ Fatty acids ( $\%$ of total): } \\
\hline iso- $13: 0$ & $8-9$ & NA & NA & $\operatorname{tr}$ & 1 \\
\hline iso- $16: 1 \omega 7 c$ & - & $5-6$ & $5-7$ & - & - \\
\hline iso- $16: 1 \omega 9 c$ & $\operatorname{tr}$ & $8-10$ & $7-8$ & 20 & 28 \\
\hline $17: 0$ & $\operatorname{tr}$ & $7-8$ & $5-6$ & $\operatorname{tr}$ & $\operatorname{tr}$ \\
\hline Summed feature 3 & $17-20$ & $\mathrm{NA}$ & NA & 10 & 10 \\
\hline \multicolumn{6}{|l|}{ Quinones ( $\%$ of total):* } \\
\hline Q-7 & 0 & 16 & 25 & 33 & NA \\
\hline Q-8 & 77 & 20 & 17 & 20 & NA \\
\hline MK-6 & 5 & 0 & 0 & 0 & NA \\
\hline MK-7 & 17 & 63 & 52 & 47 & NA \\
\hline \multicolumn{6}{|l|}{ Polar lipids: $\dagger$} \\
\hline Unknown ninhydrin-positive phospholipid & - & + & + & + & + \\
\hline \multicolumn{6}{|l|}{ Biolog profile: } \\
\hline Maltose & - & + & $+/ \mathrm{ND}$ & - & - \\
\hline Lactate & - & $\mathrm{v}$ & $+/ \mathrm{ND}$ & + & + \\
\hline DNA G $+\mathrm{C}$ content $(\mathrm{mol} \%)$ & $50-51$ & 60 & $60-61$ & 58 & 57 \\
\hline
\end{tabular}

${ }^{\star}$ Data for F. futtsuensis were obtained through personal communication with Dr Tatsunori Nakagawa.

$\dagger$ Data obtained during this study.

The fluorometric method of Ezaki et al. (1989) was used for DNA-DNA hybridization in $25 \%$ formamide at $55^{\circ} \mathrm{C}$. The DNA-DNA hybridization values between the novel Mok strains were relatively high (from $45 \pm 4 \%$ to $106 \pm 8 \%$ ), but the relatedness values between any of the novel Mok strains and F. marina and F. balearica were insignificant (ranging from $3 \pm 1 \%$ to $10 \pm 3 \%$ ) (see Supplementary Table S1, available in IJSEM Online). The DNA-DNA hybridization values between strains Mok- $106^{\mathrm{T}}$ and Mok142 were around $70 \%$, indicating that these two strains belong to the same species. Although the DNA-DNA hybridization values between strains Mok- $106^{\mathrm{T}}$ and Mok-143 were below $70 \%$ (the threshold value for membership of the same species; Wayne et al., 1987), the values found between strains Mok-142 and Mok-143 indicated that these two strains belong to the same species. As we did not find any phenotypic differences to suggest that strain Mok-143 represents a separate species from that represented by the other two Mok strains, we propose that all three novel Mok strains belong to the same species.

The low levels of $16 \mathrm{~S}$ rRNA gene sequence similarity (94\% and below) between the three novel Mok strains and members of the genus Ferrimonas and other related genera, together with the differences in the whole-cell fatty acids, quinone profiles, physiological characteristics and DNA
$\mathrm{G}+\mathrm{C}$ contents (Table 2) between members of the genus Ferrimonas and the novel Mok strains suggest that strains Mok-106 ${ }^{\mathrm{T}}$, Mok-142 and Mok-143 do not belong to the genus Ferrimonas and should be classified as members of a novel genus of the family Ferrimonadaceae. Strains Mok$106^{\mathrm{T}}$, Mok-142 and Mok-143 represent a new genus and novel species, for which the name Paraferrimonas sedimenticola gen. nov., sp. nov. is proposed.

\section{Description of Paraferrimonas gen. nov.}

Paraferrimonas (Pa.ra.fer.ri.mo'nas. Gr. prep. para beside; N.L. fem. n. Ferrimonas a bacterial genus name; N.L. fem. n. Paraferrimonas beside Ferrimonas).

Cells are Gram-negative, facultatively anaerobic rods that are motile by means of single polar flagellum. $\mathrm{NaCl}$ is required for growth. Reduce $\mathrm{Fe}(\mathrm{III})$ to $\mathrm{Fe}(\mathrm{II})$. Major quinones are Q-8 (>70\%), MK-7 (approx. 10-20\%) and MK-6 $(<10 \%)$. Major cellular fatty acids are iso-15:0, summed feature $3(16: 1 \omega 7 c$ and/or iso-15:0 2-OH), $18: 1 \omega 7 c, 16: 0$ and iso-13:0. The DNA G $+\mathrm{C}$ content is $50-51 \mathrm{~mol} \%$. The major polar lipids are PG and PE. The genus Paraferrimonas is a member of the family Ferrimonadaceae and the type species is Paraferrimonas sedimenticola. 


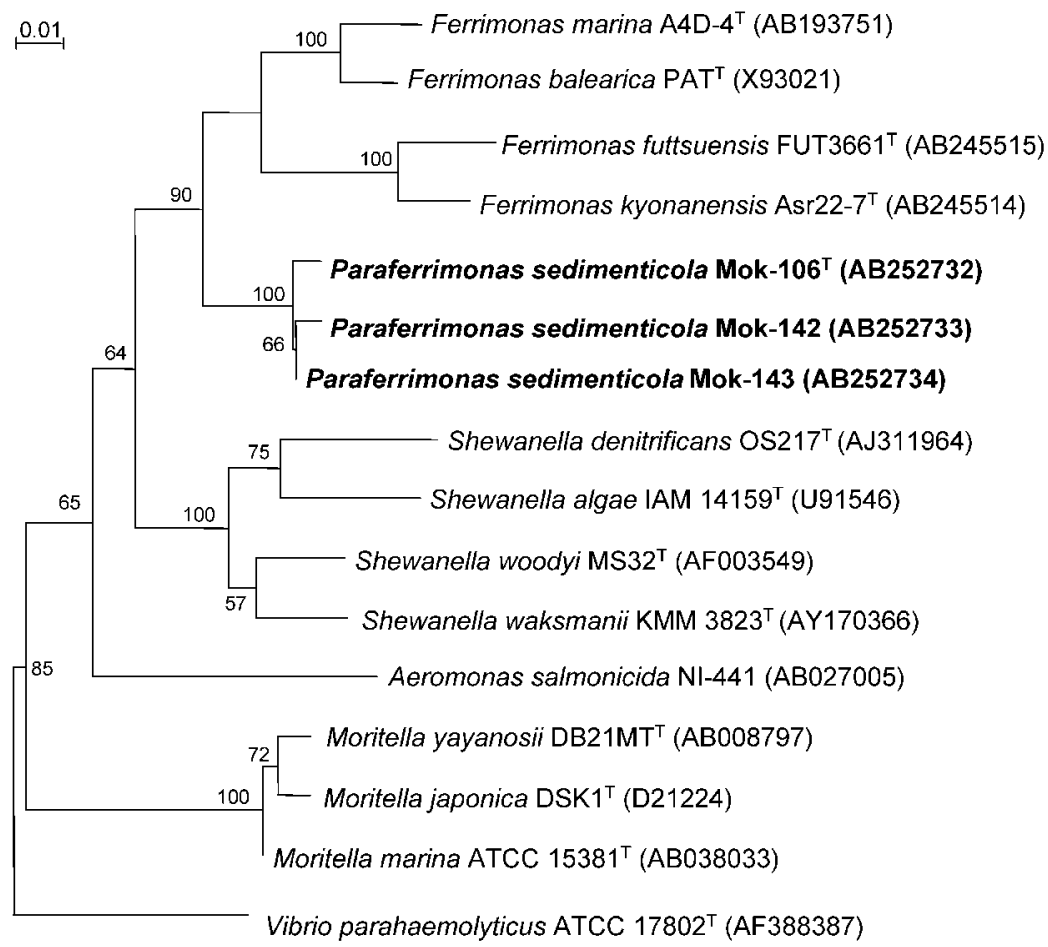

Fig. 1. Maximum-likelihood phylogenetic tree, based on almost-complete 16S rRNA gene sequences, showing the positions of strains Mok-106 ${ }^{\top}$, Mok-142 and Mok-143 within the radiation of the Gammaproteobacteria. The bootstrap support of each branch, as determined from 100 replicates, is indicated at the nodes. Sequences were downloaded from GenBank/DDBJ and the accession numbers are shown in parentheses. Vibrio parahaemolyticus was used as an outgroup. Bar, $0.01 K_{\text {nuc }}$ units.

\section{Description of Paraferrimonas sedimenticola sp. nov.}

Paraferrimonas sedimenticola (se.di.men.ti.co'la. L. neut. n. sedimentum a settling, sediment; L. suffix -cola dweller; N.L. masc. n. sedimenticola sediment dweller, referring to the isolation of the strains from sediment at Okinawa Island).

In addition to the properties given in the genus description, cells are $0.7-1.0 \mu \mathrm{m}$ in width and $1.5-2.0 \mu \mathrm{m}$ in length. Growth occurs at $15-40{ }^{\circ} \mathrm{C}$ and is optimal at $25-30{ }^{\circ} \mathrm{C}$. Cells grow in the presence of $0.5-4.0 \% \mathrm{NaCl}$. Colonies grown for more than 6 days on HSMA are rose-coloured. Growth occurs at pH 6-11, with optimal growth at pH 7.0-8.0. The major quinones are Q-8 (77-79\%), MK-7 (16-17\%) and MK-6 (4-5\%). Positive results in tests for catalase, oxidase and DNase and for degradation of aesculin and gelatin. Negative in tests for degradation of agar, starch and urea, for acid production from glucose, for indole production from tryptophan and for nitrite reduction. Tween 40, L-alanine and glycyl L-glutamic acid are oxidized on Biolog GN2 microplates. Utilizes tryptone and yeast extract when tested according to the protocol of Suzuki et al. (2001). Strain Mok-142 also oxidizes $\alpha$-D-glucose, acetic acid, L-alanyl glycine, glycyl-L-aspartic acid and L-threonine in addition to the substrates described above.

The type strain, Mok-106 ${ }^{\mathrm{T}} \quad\left(=\mathrm{NBRC} 101628^{\mathrm{T}}=\mathrm{CIP}\right.$ $109284^{\mathrm{T}}$ ), was isolated from marine sediment at Okinawa Island, Japan. Strains Mok-142 (=NBRC 101629) and Mok-143 ( = NBRC 101630) are reference strains.

\section{Acknowledgements}

This work was supported by grant no. 04000182-0 from the New Energy and Industrial Technology Development Organization (NEDO). The authors would like to thank Dr Kenji Tanaka for help with the transmission electron microscopy, Dr Tomohiko Tamura for the polar lipid analysis and Dr Tatsunori Nakagawa and Dr Takao Iino for the electron acceptor tests.

\section{References}

Adachi, J. \& Hasegawa, M. (1996). MOLPHY version 2.3 - Programs for Molecular Phylogenetics Based on Maximum-Likelihood (Computer Science Monograph no. 28). Tokyo: Institute of Statistical Mathematics.

Altschul, S. F., Gish, W., Miller, W., Myers, E. W. \& Lipman, D. J. (1990). Basic local alignment search tool. J Mol Biol 215, 403-410.

Cowan, S. T. \& Steel, K. J. (1993). Manual for the Identification of Medical Bacteria, 3rd edn. London: Cambridge University Press.

Ezaki, T., Hashimoto, Y. \& Yabuuchi, E. (1989). Fluorometric deoxyribonucleic acid-deoxyribonucleic acid hybridization in microdilution wells as an alternative to membrane filter hybridization in which radioisotopes are used to determine genetic relatedness among bacterial strains. Int J Syst Bacteriol 39, 224-229.

Felsenstein, J. (1985). Confidence limits on phylogenies: an approach using the bootstrap. Evolution 39, 783-791.

Hiraishi, A., Shin, Y. K., Ueda, Y. \& Sugiyama, J. (1994). Automated sequencing of PCR-amplified 16S rDNA on 'hydrolink' gels. J Microbiol Methods 19, 145-154.

Ivanova, E. P., Flavier, S. \& Christen, R. (2004). Phylogenetic relationships among marine Alteromonas-like proteobacteria: emended description of the family Alteromonadaceae and proposal of Pseudoalteromonadaceae fam. nov., Colwelliaceae fam. nov., Shewanellaceae fam. nov., Moritillaceae fam. nov., Ferrimonadaceae 
fam. nov., Idiomarinaceae fam. nov., and Psychromonadaceae fam. nov. Int J Syst Evol Microbiol 54, 1773-1788.

Katsuta, A., Adachi, K., Matsuda, S., Shizuri, Y. \& Kasai, K. (2005). Ferrimonas marina sp. nov. Int J Syst Evol Microbiol 55, 1851-1855.

Mesbah, M., Premachandran, U. \& Whitman, W. B. (1989). Precise measurement of the $\mathrm{G}+\mathrm{C}$ content of deoxyribonucleic acid by highperformance liquid chromatography. Int J Syst Bacteriol 39, 159-167.

Minamisawa, K. (1990). Division of rhizobitoxine-producing and hydrogen-uptake positive strains of Bradyrhizobium japonicum by nifDKE sequence divergence. Plant Cell Physiol 31, 81-89.

Minnikin, D. E., Collins, M. D. \& Goodfellow, M. (1979). Fatty acid and polar lipid composition in the classification of Cellulomonas, Oerskovia and related taxa. J Appl Bacteriol 47, 87-95.

Nakagawa, Y. \& Yamasato, K. (1993). Phylogenetic diversity of the genus Cytophaga revealed by $16 \mathrm{~S}$ rRNA sequencing and menaquinone analysis. J Gen Microbiol 139, 1155-1161.

Nakagawa, T., lino, T., Suzuki, K. \& Harayama, S. (2006). Ferrimonas futtsuensis sp. nov. and Ferrimonas kyonanensis sp. nov., selenate-reducing bacteria belonging to the Gammaproteobacteria isolated from Tokyo Bay. Int J Syst Evol Microbiol 56, 2639-2645.

Rosselló-Mora, R. A., Ludwig, W., Kämpfer, P., Amann, R. \& Schleifer, K.-H. (1995). Ferrimonas balearica gen. nov., spec. nov., a new marine facultative Fe(III)-reducing bacterium. Syst Appl Microbiol 18, 196-202.

Rüger, H.-J. \& Krambeck, H.-J. (1994). Evaluation of the BIOLOG substrate metabolism system for classification of marine bacteria. Syst Appl Microbiol 17, 281-288.
Saitou, N. \& Nei, M. (1987). The neighbor-joining method: a new method for reconstructing phylogenetic trees. Mol Biol Evol 4, 406-425.

Suzuki, M., Nakagawa, Y., Harayama, S. \& Yamamoto, S. (2001). Phylogenetic analysis and taxonomic study of marine Cytophaga-like bacteria: proposal for Tenacibaculum gen. nov., with Tenacibaculum maritimum comb. nov. and Tenacibaculum ovolyticum comb. nov., and description of Tenacibaculum mesophilum sp. nov. and Tenacibaculum amylolyticum sp. nov. Int J Syst Evol Microbiol 51, 1639-1652.

Swofford, D. L. (2000). PAUP*: Phylogenetic analysis using parsimony ( ${ }^{*}$ and other methods), version 4. Sunderland, MA: Sinauer Associates.

Thompson, J. D., Gibson, T. J., Plewniak, F., Jeanmougin, F. \& Higgins, D. G. (1997). The CLUSTAL_X windows interface: flexible strategies for multiple sequence alignment aided by quality analysis tools. Nucleic Acids Res 25, 4876-4882.

Wayne, L. G., Brenner, D. J., Colwell, R. R., Grimont, P. A. D., Kandler, O., Krichevsky, M. I., Moore, L. H., Murray, R. G. E., Stackebrandt, E. \& other authors (1987). International Committee on Systematic Bacteriology. Report of the ad hoc committee on reconciliation of approaches to bacterial systematics. Int $J$ Syst Bacteriol 37, 463-464.

Widdel, F., Kohring, G.-W. \& Myer, F. (1983). Studies on dissimilatory sulfate-reducing bacteria that decompose fatty acids. III. Characterization of the filamentous gliding Desulfonema limicola gen. nov., sp. nov., and Desulfonema magnum sp. nov. Arch Microbiol 134, 286-294. 